\title{
Ecotourism Impact Assessment on Environment in Protected Areas of Serbia: A Case Study of Gornje Podunavlje Special Nature Reserve
}

\author{
Vladimir StojanovićA, Maja Mijatov ${ }^{*}$, Jelena DunjićA , Lazar LazićA, \\ Aleksandra Dragin ${ }^{A}$, Dubravka Milić ${ }^{B}$, Sanja Obradović ${ }^{A}$ \\ Received: May 21, 2021 | Revised: June 17, 2021 | Accepted: July 10, 2021 \\ doi: 10.5937/gp25-32288
}

\begin{abstract}
Ecotourism is a nature-based type of tourism, especially represented within protected areas. No matter the fact, just like the other selective types of this sector, ecotourism might affect the environment. In a process of writing the Visitor Management Plan in the Gornje Podunavlje Special Nature Reserve (SNR) in 2019, one part of the study was related to general projection of the ecotourism development impact on eco-educational paths within this SNR. The research was conducted throughout November 2019, in the form of interviews. The sample obtained 12 experts for nature protection, who stated their attitudes on three important topics: tourism in protected areas in general, tourism in the Gornje Podunavlje SNR and ecotourism within three concrete sites: Karapandža, Štrbac and Bestrement.
\end{abstract}

Keywords: ecotourism; protected areas; impact assessment; experts' attitudes; nature protection; plant sensitivity; animal sensitivity

\section{Introduction}

Nature-based tourism, including ecotourism, has a range of negative effects on the environment (Buckley, 2004a, 2004b, 2004c). In order to minimize such negative effects, protected areas managers are following different infrastructural and technical details. Considering specific characteristics of localities, there are concrete measures that must be applied to each path separately (Hockett et al., 2017; Kidd et al., 2015; Tomczyk \& Ewertowski, 2013). However, besides infrastructural and technical measures, it is also important to provide assessment of the impact of tourism activities on natural resources within the paths, which is strongly related to the process of monitoring the plant and animal species (Asmelash \& Kumar, 2019; Blancas et al., 2016; Laimer, 2017; Kristjánsdóttir et al., 2018; Mapjabil et al., 2017).

Raising concern about the tourism impact on the environment initiated the need for more sustainable forms of tourism, which led to the ecotourism development in the late 1980s (Donohoe \& Needham, 2006) and since than it became a growing industry (Carvache-Franco et al., 2020). One of the first of definitions of ecotourism explain that 'we may define ecological tourism or ecotourism as that tourism that involves travelling to relatively undisturbed or uncontaminated natural areas with the specific object of stud-

\footnotetext{
A University of Novi Sad, Faculty of Sciences, Department of Geography, Tourism and Hotel Management, Trg Dositeja Obradovića 3, 21000, Novi Sad, Serbia; vladimir.stojanovic@dgt.uns.ac.rs; majamijatov@gmail.com; jelenad@dgt.uns.ac.rs; lazar.lazic@dgt.uns.ac.rs; sadragin@gmail.com; sanjaobradovic992@gmail.com

B University of Novi Sad, Faculty of Sciences, Department of Biology and Ecology, Trg Dositeja Obradovića 2, 21000, Novi Sad, Serbia; dubravka.milic@ube.uns.ac.rs

* Corresponding author: Maja Mijatov; e-mail: majamijatov@gmail.com
} 
ying, admiring and enjoying the scenery and its wild plants and animals' (Ceballos-Lascurain, 1996). Ecotourism is a nature-based type of tourism where educational component is well emphasized. This means that tourists are given the opportunity to gain awareness and knowledge about nature and its conservation (flora, fauna, geology and ecosystems of an area), sustainable practices, the methods for participation of local communities and ethical planning, development and management (Šiljeg et al., 2019). It is one of the few opportunities for the poor to support and promote sustainable development (Goodwin, 2009).

The link between protected areas and tourism is as old as the history of protected areas. This connection is mutual, since both tourism and protected areas need each other in order to achieve their full potential (Eagles et al., 2002). Even though ecotourism is considered to be an activity with a low impact on nature (Pablo-Cea et al., 2021), the impacts of ecotourism on protected areas could still be negative (Buckley, 2001).

Nevertheless, there are many contributions that ecotourism development could generate for the biodiversity conservation. First, it could generate additional financial resources obtained from visitation fees and donations, which could be helpful to protected area management. Then, it could contribute to raising awareness of visitors, encouragement of community involvement and interest in conservation issues and generating political support for conservation through environmental education during travel (Christ et al., 2003). For some countries, benefits derived from in- terest in biodiversity is an especially important source of revenue. On the other hand, in some cases protected areas become so popular among visitors that there is cause for concern as to the consequences of high frequentation for the preservation of the sites (Lévêque \& Mounolou, 2003).

In this study we investigate the major impacts of tourism development to natural resources of protected areas according to the experts in the field of nature protection. The main issue with tourism development in protected areas is that it puts certain pressure to the resources. On the other hand, it generates benefits for the destination as well. Therefore, identifying the major impacts and mitigating them in early stages of tourism development would have major contribution to achievement of sustainable development. There is a certain gap between realistic situation in the field and academic contribution to this problem. Therefore, this study aims to provide an insight into the attitudes of the experts for nature protection of the Gornje Podunavlje Special Nature Reserve (SNR), in order to emphasize the need for harmonizing the further activities of ecotourism and nature protection within the study area. The results are beneficial to multiple stakeholders, such as managers of other protected areas, giving them the starting point to creating visitors' guidelines, or establishing more restricted zones for tourists according to the vulnerability of the area or species. Other academics could use the results as the insight into the issues on field, which are often omitted in academic literature.

\section{Study area}

Gornje Podunavlje SNR is located within peripheral, northwestern part of Serbia (19,648 ha). It stretches along the left bank of the Danube River and includes numerous meanders, oxbow lake, canals, or more precisely aquatic, marsh, meadow and forest ecosystems (Figure 1).

Protected area of Gornje Podunavlje is the most recognizable by the well-preserved features of the floodplain along the Danube River (Panjković \& Stojnić, 2011). The value of the ecosystems of Gornje Podunavlje Region is reflected in the fact that they represent one of the rarely preserved natural landscapes in predominantly agrarian environment of northern Serbia, as well as in the fact that this area provides numerous opportunities for development of tourism (Lazić et al., 2008; Stojanović et al., 2018).

The living world of Gornje Podunavlje SNR is rich, diverse, specific and unique, with a large number of rare and unthreatened plant and animal species of national and international importance. Its vegetation is built of 57 herbaceous, forest, and shrubby plant communities. Another part of diversity of the living world of the Gornje Podunavlje SNR is reflected in the presence of 60 species of diurnal butterflies, 55 species of fish, 11 species of amphibians, nine species of reptiles, over 230 species of birds and 51 species of mammals. This SNR is also a hatchery ground for fish, as well as a nesting place for white-tailed eagle and black storks. Finally, this protected area is perhaps the best known as a habitat with the regionally richest population of marsh deer and wild boar (Ministry of Environmental Protection, 2007).

The Gornje Podunavlje SNR is also an area of international importance: Ramsar site (wetland of international importance), IBA - Important Bird Area, IPA - Important Plant Area (Panjković \& Stojnić, 2011). SNR is part of the Bačko Podunavlje Biosphere Reserve, which was declared in 2016 (Tucakov, 2018).

The ecotourism policy highlights three main zones of ecotourism development in the Gornje Podunavlje SNR: Karapandža, Štrbac and Bestrement. These 


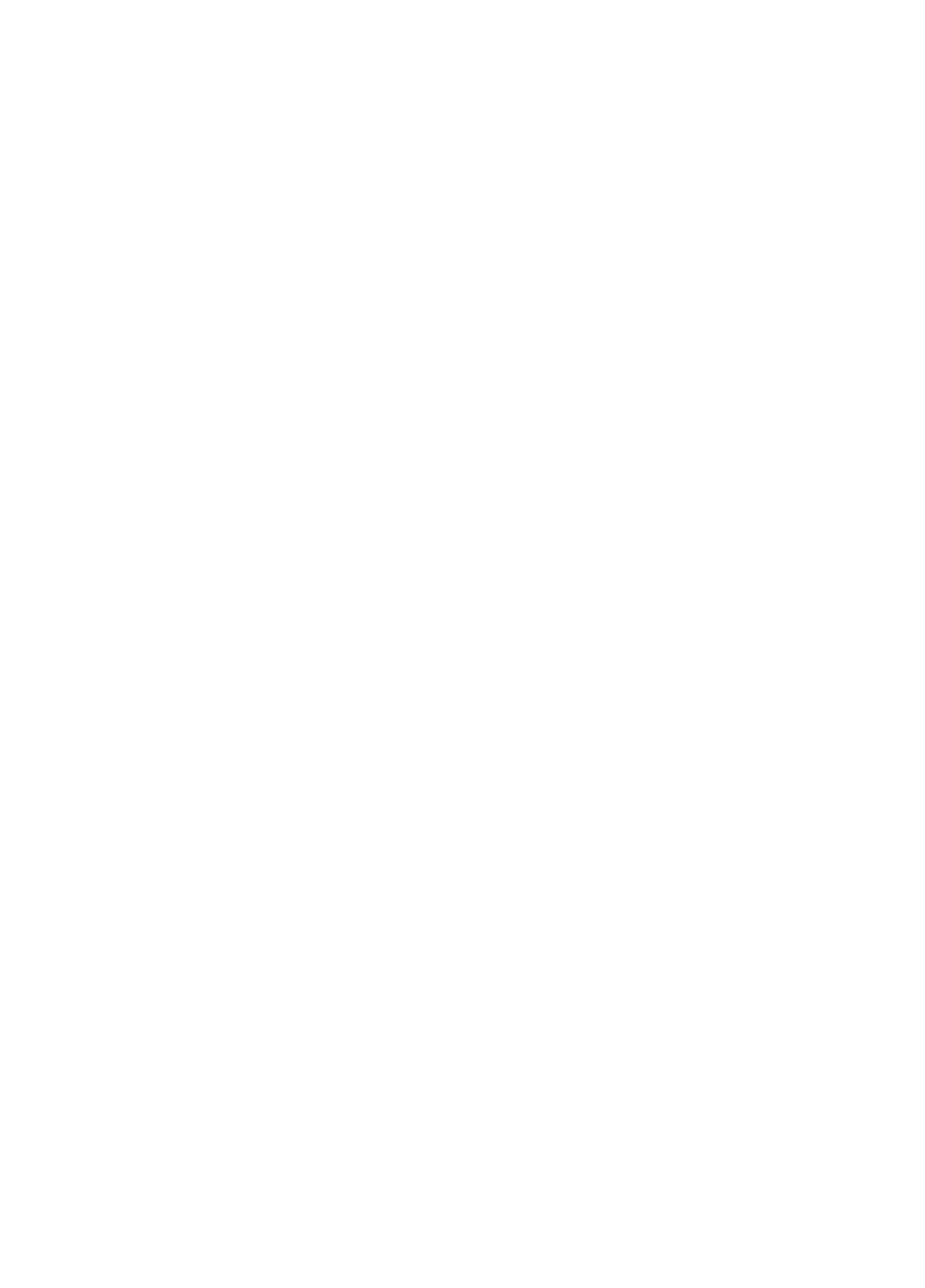

Figure 1. Special Nature Reserve "Gornje Podunavlje" [click on figure to enlarge]

zones enable approximate distribution of contents of ecotourism on the level of this SNR, considering that
Karapandža is located in its northern part, Štrbac in the central part and Bestrement in its southern part.

\section{Methodology}

\section{Procedure}

The research was conducted in November 2019, as a part of the of the wider study "Visitor Management Plan in the Gornje Podunavlje Special Nature Reserve (SNR)" (2019). The main idea was to conduct preliminary (pilot) study which aimed to identify the main challenges that experts from the SNR Gornje Podunavlje are facing with, as well as key impacts of ecotourism on protected area and priority areas for protection. The first draft of the questions in the questionnaire was created according to the similar problem mentioned in the academic literature (Blancas et al., 2016; Hockett et al., 2017; Tomczyk et al. 2013). Later we conducted the first round of the interviews with the experts from the
SNR Gornje Podunavlje, and according to their reallife challenges, we added variables to the questionnaire. Second round of the interview was conducted among the experts with the final questionnaire. The final questionnaire was conducted on the basis of the exploratory design with semi-structured interview protocol. Collected data were coded by using the thematic analysis with data driven inductive-realistic epistemological approach (Robson \& McCartan, 2016; Terry et al., 2017) and they were summarized on the basis of the meaning condensation (Kvale, 1996). Such approach was identified as the most appropriate one, considering the main goal of this research, focused on discovering the attitudes of the experts for nature protection of specific 
environment, in this case the Gornje Podunavlje SNR. Besides that, the research was oriented towards coding the collected data, in order to fill the gap in the lack of theoretical frameworks for the assessment of the ecotourism impact on the environment in this SNR. During the procedure of data collecting, the respondents preferred to answer the interview questions by e-mails.

\section{Sample}

The main idea was to gather the relevant data, based on the attitudes of 12 experts for the nature protection, who are introduced with the real situation of ecotourism impact on the environment within the study area. Therefore, the main idea of the research was to provide reliable findings, based on the attitudes of the experts who are involved in managing and monitoring the situation of ecotourism in the Gornje Podunavlje Special Nature Reserve, as well as in biological and geographical research of the study area, in order to provide the real assessment and proposals for reduction of ecotourism negative effects on the environment. The sample could be divided into the three groups. The first group gathered four employees in the Gornje Podunavlje SNR Authority (the Public Enterprise 'Vojvodinašume'). Besides that, four experts from the Institute for Nature Conservation of Vojvodina Province (INCVP) in Novi Sad, the leading institution for nature protection in Vojvodina (North Serbia), are introduced with the main characteristics of the Gornje Podunavlje SNR and they represent the second group of the sample. Finally, the third group gathered the University professors, biologists and geographers - experts for nature protection, as the main researchers dealing with the issues of importance for the environment preservation of the study area.

\section{Instrument and Data Analysis}

The questions for the interview were formed precisely for the purpose of this research. On the one hand, they were based on the literature review on the main issues of ecotourism impact on the environment in protected areas worldwide (Blancas et al., 2016; Hockett et al., 2017; Tomczyk et al. 2013), while on the other hand they also represent a result of the previously conducted field research that provided an insight into the real situation of nature protection in SNR Gornje Podunavlje and which served as guidance for further research of ecotourism impact on nature protection. All together resulted in 17 defined question items. All thematic codes with the same meaning were grouped into the several themes that were used during the data analysis and interpretation procedures. The first theme referred to the respondents' general attitudes on tourism in protected areas and it was researched on the basis of five items (Tourism in protected are- as might contribute to a better understanding of nature protection; Tourism represents a threat to protected areas; Tourists in protected areas should always be under the Protected Areas Managers' supervision; Projects of nature protection might be financed by the incomes gained for providing tourism services; The local community has important role in tourism of protected areas). The second theme obtained five items regarding tourism in the Gornje Podunavlje SNR (Tourism in the Gornje Podunavlje SNR represents a chance for successful and active nature protection; Tourism in the Gornje Podunavlje SNR might be a threat for protected natural values; Development of tourism in the Gornje Podunavlje SNR is on satisfying level; Ecotourism in the Gornje Podunavlje SNR is optimally developed; The local community is sufficiently involved in tourism of the Gornje Podunavlje SNR). The final third theme included seven items related to ecotourism, within three concrete sites in this SNR, or more precisely in Karapandža, Štrbac and Bestrement (Tours across the educational paths in Karapandža represent a threat for protected species and habitats; Tours across the educational path in Štrbac represent a threat for protected species and habitats; Tours across the educational path in Bestrement represent a threat for protected species and habitats; Karapandža, Štrbac and Bestrement encompass some of the most important values of the Gornje Podunavlje SNR; Ecotourism within Karapandža, Štrbac and Bestrement might contribute to gaining complete experience of the Gornje Podunavlje SNR; Ecotourism (education, interpretation) should be developed on the other localities within the Gornje Podunavlje SNR, outside three researched ones; Ecotourism within Karapandža, Štrbac and Bestrement encourages nature protection.). All gathered responses were summarized in order to briefly represent the attitudes of the experts for nature protection of the Gornje Podunavlje SNR. Respondents expressed their attitudes on the scale, ranging from 1 (completely disagree) to 5 (completely agree). They were asked three additional open-ended questions for expressing their wider attitudes related to the plant and animal species sensitivity and necessary measures in further ecotourism development (Are some plant species and communities in Karapandža, Štrbac and Bestrement particularly sensitive in relation to ecotourism tourism activities (walking, education, volunteering) and which ones? Are some animal species in Karapandža, Štrbac and Bestrement particularly sensitive in relation to ecotourism tourism activities (walking, education, volunteering) and which ones? In your opinion, is it necessary to implement concrete special measures in the process of realization of ecotourism in Karapandža, Štrbac and Bestrement in order to avoid the negative influences of tourism and which ones?). 


\section{Results}

The research results of conducted interviews and further analysis of collected data will firstly be represented in the form of the findings for three defined themes separately, which will be followed with the representation of findings in a summary form. Findings will be discussed as a whole, while thematic relationship patterns will be elaborated and linked to a formal body of knowledge on the topic of the ecotourism impact on the Gornje Podunavlje SNR.

\section{Tourism in protected areas}

Employees of the Gornje Podunavlje SNR Authority completely agreed with the fact that tourism within protected areas might contribute to a better understanding of nature protection (Table 1). A slightly lower average score $(\mathrm{M}=4.75)$ was recorded for this item within the group of INCVP experts and University professors.

Most of the employees in the Gornje Podunavlje SNR Authority $(\mathrm{M}=4.50)$ and INCVP experts $(\mathrm{M}=$ 4.25) completely agreed with the fact that tourists in protected areas must always be under the supervision of their Authorities. University professors are sharing their opinions $(M=4.25)$.

University professors completely agreed with the fact that nature protection projects might be financed from the incomes realized on the basis of providing tourism services $(M=5.00)$, while INCVP experts expressed slightly lower mean value $(M=4.00)$. Much lower mean value and almost indefinite attitude was recorded in the case of the employees in the Gornje Podunavlje SNR Authority $(\mathrm{M}=3.00)$.
Besides that, INCVP experts, as well as University professors, fully agreed with the fact that local population has an important role in tourism within protected areas $(M=5.00)$. Majority of the employees in the Gornje Podunavlje SNR Authority share the same attitude $(\mathrm{M}=4.75)$.

The lowest scores were recorded in the case of the respondents' attitudes regarding the fact that tourism might be a threat to protected areas (INCVP experts: $\mathrm{M}=3.25$; University professors: $\mathrm{M}=2.25$; employees in the Gornje Podunavlje SNR Authority: $M=1.75$ ).

\section{Tourism in the Gornje Podunavlje SNR}

Employees in the Gornje Podunavlje SNR Authority and INCVP experts, completely or partially agreed with the fact that tourism development within this $\mathrm{SNR}$ is a chance for active nature protection $(\mathrm{M}=$ 4.50) (Table 2). University professors indicated complete agreement $(\mathrm{M}=5.00)$.

INCVP experts and University professors partially agreed with the fact that tourism within this SNR might be a potential threat for protected natural species $(M=3.25)$. Employees in the Gornje Podunavlje SNR Authority mainly believe that, in its current form of development, tourism does not represent a threat $(\mathrm{M}=2.00)$.

Lower scores were recorded for INCVP experts' and University professors' attitudes on whether tourism in the Gornje Podunavlje SNR is sufficiently developed $(M=2.25)$. Mean value for the employees in the Gornje Podunavlje SNR Authority is even lower $(\mathrm{M}=1.75)$. Similar attitudes were recorded regarding the optimal development of ecotourism in this SNR.

Table 1. Respondents' attitudes on tourism in protected areas

\begin{tabular}{|c|c|c|c|c|c|c|}
\hline \multirow{2}{*}{$\begin{array}{l}\text { Item } \\
\text { Tourism in protected areas }\end{array}$} & \multicolumn{2}{|c|}{$\begin{array}{l}\text { Employees in the Gornje } \\
\text { Podunavlje SNR Authority }\end{array}$} & \multicolumn{2}{|c|}{ INCVP experts } & \multicolumn{2}{|c|}{ University professors } \\
\hline & $\begin{array}{l}\text { Mean } \\
\text { Value }\end{array}$ & $\begin{array}{l}\text { Standard } \\
\text { Deviation }\end{array}$ & $\begin{array}{l}\text { Mean } \\
\text { Value }\end{array}$ & $\begin{array}{l}\text { Standard } \\
\text { Deviation }\end{array}$ & $\begin{array}{l}\text { Mean } \\
\text { Value }\end{array}$ & $\begin{array}{l}\text { Standard } \\
\text { Deviation }\end{array}$ \\
\hline $\begin{array}{l}\text { Tourism in protected areas might } \\
\text { contribute to a better understanding } \\
\text { of nature protection. }\end{array}$ & 5.00 & .00 & 4.75 & .50 & 4.75 & .50 \\
\hline $\begin{array}{l}\text { Tourism represents a threat to } \\
\text { protected areas. }\end{array}$ & 1.75 & 1.50 & 3.25 & .96 & 2.25 & 1.26 \\
\hline $\begin{array}{l}\text { Tourists in protected areas should } \\
\text { always be under the Protected Areas } \\
\text { Managers' supervision. }\end{array}$ & 4.50 & 1.00 & 4.25 & 1.50 & 4.25 & .50 \\
\hline $\begin{array}{l}\text { Projects of nature protection might } \\
\text { be financed by the incomes gained for } \\
\text { providing tourism services. }\end{array}$ & 3.00 & .82 & 4.00 & 2.00 & 5.00 & .00 \\
\hline $\begin{array}{l}\text { The local community has important } \\
\text { role in tourism of protected areas. }\end{array}$ & 4.75 & .50 & 5.00 & .00 & 5.00 & .00 \\
\hline
\end{tabular}


Table 2. Respondents' attitudes on tourism in the Gornje Podunavlje SNR

\begin{tabular}{|c|c|c|c|c|c|c|}
\hline \multirow{2}{*}{$\begin{array}{l}\text { Item } \\
\text { Tourism in the Gornje Podunavlje } \\
\text { SNR }\end{array}$} & \multicolumn{2}{|c|}{$\begin{array}{l}\text { Employees in the Gornje } \\
\text { Podunavlje SNR Authority }\end{array}$} & \multicolumn{2}{|c|}{ INCVP experts } & \multicolumn{2}{|c|}{ University professors } \\
\hline & $\begin{array}{l}\text { Mean } \\
\text { Value }\end{array}$ & $\begin{array}{l}\text { Standard } \\
\text { Deviation }\end{array}$ & $\begin{array}{l}\text { Mean } \\
\text { Value }\end{array}$ & $\begin{array}{l}\text { Standard } \\
\text { Deviation }\end{array}$ & $\begin{array}{l}\text { Mean } \\
\text { Value }\end{array}$ & $\begin{array}{l}\text { Standard } \\
\text { Deviation }\end{array}$ \\
\hline $\begin{array}{l}\text { Tourism in the Gornje Podunavlje SNR } \\
\text { represents a chance for successful and } \\
\text { active nature protection. }\end{array}$ & 4.50 & 1.00 & 4.50 & .58 & 5.00 & .00 \\
\hline $\begin{array}{l}\text { Tourism in the Gornje Podunavlje } \\
\text { SNR might be a threat for protected } \\
\text { natural values. }\end{array}$ & 2.00 & 1.41 & 3.25 & .96 & 3.25 & .96 \\
\hline $\begin{array}{l}\text { Development of tourism in the Gornje } \\
\text { Podunavlje SNR is on satisfying level. }\end{array}$ & 1.75 & .50 & 2.25 & .50 & 2.25 & .50 \\
\hline $\begin{array}{l}\text { Ecotourism in the Gornje Podunavlje } \\
\text { SNR is optimally developed. }\end{array}$ & 2.00 & .82 & 1.75 & .50 & 2.75 & .96 \\
\hline $\begin{array}{l}\text { The local community is sufficiently } \\
\text { involved in tourism of the Gornje } \\
\text { Podunavlje SNR. }\end{array}$ & 2.75 & .50 & 2.00 & 1.41 & 2.75 & .50 \\
\hline
\end{tabular}

Majority of the employees in the Gornje Podunavlje SNR Authority and University professors, believe that members of the local community are not sufficiently involved in development of tourism in this protected area $(\mathrm{M}=2.75)$, while even lower mean value was recorded in the case of INCVP experts $(M=2.00)$.

\section{Ecotourism within Karapandža, Štrbac and Bestrement}

In the case of the attitudes of INCVP experts and University professors regarding the ecotourism development within three researched sites (Table 3), it should be noted that all of them agreed with the fact that Karapandža, Štrbac and Bestrement obtain some of the most important natural resources of this SNR (M $=5.00$ ). Slightly lower mean value for this statement was recorded in the case of the employees in the Gornje Podunavlje SNR Authority $(\mathrm{M}=4.75)$.

Most of INCVP experts and University professors completely or partially agreed with the fact that ecotourism needs to be developed in other sites of this protected area, besides within the territory of Karapandža, Štrbac and Bestrement, as three localities of the Gornje Podunavlje Special Nature Reserve, obtained by this research $(\mathrm{M}=4.75)$. Employees in the Gornje Podunavlje SNR Authority expressed indefinite attitude or complete disagreement with this statement $(M=2.50)$.

Furthermore, employees in the Gornje Podunavlje SNR Authority and INCVP experts expressed the same attitude regarding the fact that ecotourism in these three mentioned sites encourages appropriate nature protection $(\mathrm{M}=4.50)$. University professors showed slightly lower positive attitudes on the same claim $(\mathrm{M}=4.25)$.

INCVP experts partially agreed with the fact that visits to educational paths $n$ Karapandža might threat protected species and habitats $(M=3.25)$. Employees in the Gornje Podunavlje SNR Authority expressed complete or partial disagreement with this statement $(\mathrm{M}=1.25)$, while similar attitude was recorded for University professors $(\mathrm{M}=1.75)$.

Slightly lower score was recorded for the item related to INCVP experts' attitudes on whether the visits to educational paths in Štrbac and Bestrement might threat protected species and habitats $(M=3.00)$. Similar mean values were recorded for University professors $(\mathrm{M}=2.00)$ and the employees in the Gornje Podunavlje SNR Authority $(\mathrm{M}=1.50)$.

Finally, attitudes of INCVP experts on whether the ecotourism in Karapandža, Štrbac and Bestrement might contribute to gaining the overall experience of the Gornje Podunavlje SNR remains undefined. Attitudes of the employees in the Gornje Podunavlje SNR Authority $(\mathrm{M}=4.50)$ and University professors $(\mathrm{M}=$ 4.25) are more concrete.

\section{Interview Summary}

The interview data revealed that experts for nature protection of the Gornje Podunavlje SNR share the attitude that plant and animal species, especially the protected ones, are not endangered by the current level of ecotourism development in this Protected Area, primary within three researched sites, Karapandža, Štrbac and Bestrement. However, it could be said that all of them are aware of potential negative effects that might be caused by increased number of tourists' visits. Besides the current efforts in terms of the ecotourism activities, they indicated expressed awareness of the need for systematic and planned activities in the field of further ecotourism development, with special reference to raising the education of the visitors in terms of nature protection and involvement of the 
Table 3. Respondents' attitudes on ecotourism in Karapandža, Štrbac and Bestrement

\begin{tabular}{|c|c|c|c|c|c|c|}
\hline \multirow{2}{*}{$\begin{array}{l}\text { Item } \\
\text { Tourism in Karapandža, Štrbac } \\
\text { and Bestrement }\end{array}$} & \multicolumn{2}{|c|}{$\begin{array}{l}\text { Employees in the Gornje } \\
\text { Podunavlje SNR Authority }\end{array}$} & \multicolumn{2}{|c|}{ INCVP experts } & \multicolumn{2}{|c|}{ University professors } \\
\hline & Mean Value & $\begin{array}{l}\text { Standard } \\
\text { Deviation }\end{array}$ & Mean Value & $\begin{array}{l}\text { Standard } \\
\text { Deviation }\end{array}$ & Mean Value & $\begin{array}{l}\text { Standard } \\
\text { Deviation }\end{array}$ \\
\hline $\begin{array}{l}\text { Tours across the educational paths } \\
\text { in Karapandža represent a threat for } \\
\text { protected species and habitats. }\end{array}$ & 1.25 & .50 & 3.25 & 1.50 & 1.75 & .96 \\
\hline $\begin{array}{l}\text { Tours across the educational path } \\
\text { in Štrbac represent a threat for } \\
\text { protected species and habitats. }\end{array}$ & 1.50 & 1.00 & 3.00 & 1.41 & 2.00 & .82 \\
\hline $\begin{array}{l}\text { Tours across the educational path } \\
\text { in Bestrement represent a threat for } \\
\text { protected species and habitats. }\end{array}$ & 1.50 & 1.00 & 3.00 & 1.41 & 2.00 & .82 \\
\hline $\begin{array}{l}\text { Karapandža, Štrbac and Bestrement } \\
\text { encompass some of the most } \\
\text { important values of the Gornje } \\
\text { Podunavlje SNR. }\end{array}$ & 4.75 & .50 & 5.00 & .00 & 5.00 & .00 \\
\hline $\begin{array}{l}\text { Ecotourism within Karapandža, Štrbac } \\
\text { and Bestrement might contribute to } \\
\text { gaining complete experience of the } \\
\text { Gornje Podunavlje SNR. }\end{array}$ & 4.50 & .58 & 3.00 & 1.41 & 4.25 & .96 \\
\hline $\begin{array}{l}\text { Ecotourism (education, interpretation) } \\
\text { should be developed on the other } \\
\text { localities within the Gornje Podunavlje } \\
\text { SNR, outside three researched ones. }\end{array}$ & 2.50 & 1.00 & 4.75 & .50 & 4.75 & .50 \\
\hline $\begin{array}{l}\text { Ecotourism within Karapandža, Štrbac } \\
\text { and Bestrement encourages nature } \\
\text { protection. }\end{array}$ & 4.50 & .58 & 4.50 & .58 & 4.25 & .50 \\
\hline
\end{tabular}

local community in such activities. Causal thematic network illustrates this summary (Figure 2).

Besides that, respondents showed positive attitudes on tourism in protected areas (Table 4), especially in terms of the fact that the local community should be involved in further development $(\mathrm{M}=4.92)$, as well as the fact that tourism in protected areas might contribute to a better understanding of nature protection
$(\mathrm{M}=4.83)$. The lowest mean value was recorded for the item which is indicating that tourism represent a threat for protected areas $(M=2.42)$. Findings are also indicating the fact that tourism in the Gornje Podunavlje SNR represents a chance for active nature protection $(M=4.67)$, which is not sufficiently utilized, considering the fact that tourism development in this SNR still did not reach the satisfying level $(\mathrm{M}=2.08)$.

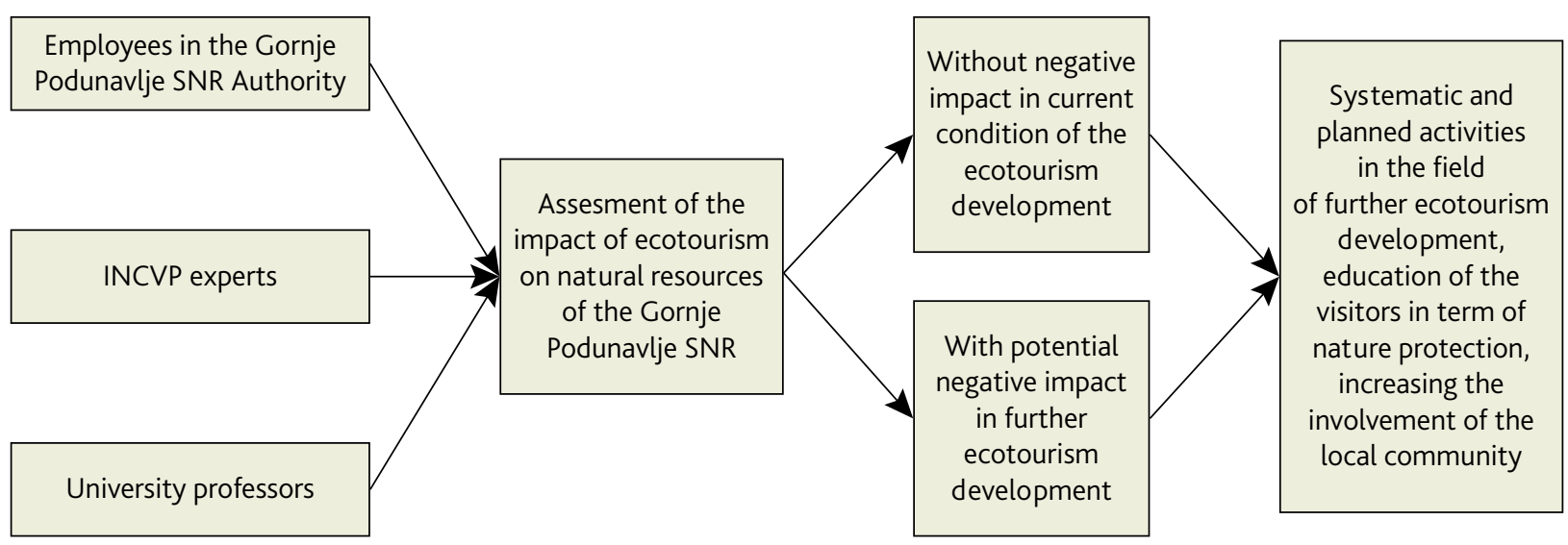

Figure 2. Key constructs in ecotourism development within the Gornje Podunavlje SNR 
Table 4. Summarized respondents' attitudes

\begin{tabular}{|c|c|c|}
\hline Item & Mean Value & Standard Deviation \\
\hline Tourism in protected areas & 4.10 & .54 \\
\hline $\begin{array}{l}\text { Tourism in protected areas might contribute to a better understanding of nature } \\
\text { protection. }\end{array}$ & 4.83 & .39 \\
\hline Tourism represents a threat to protected areas. & 2.42 & 1.31 \\
\hline $\begin{array}{l}\text { Tourists in protected areas should always be under the Protected Areas Managers' } \\
\text { supervision. }\end{array}$ & 4.33 & .99 \\
\hline $\begin{array}{l}\text { Projects of nature protection might be financed by the incomes gained for } \\
\text { providing tourism services. }\end{array}$ & 4.00 & 1.41 \\
\hline The local community has important role in tourism of protected areas. & 4.92 & .29 \\
\hline Tourism in the Gornje Podunavlje SNR & 2.85 & .54 \\
\hline $\begin{array}{l}\text { Tourism in the Gornje Podunavlje SNR is a chance for successful/active nature } \\
\text { protection. }\end{array}$ & 4.67 & .65 \\
\hline $\begin{array}{l}\text { Tourism in the Gornje Podunavlje SNR might be a threat for protected natural } \\
\text { values. }\end{array}$ & 2.83 & 1.19 \\
\hline Development of tourism in the Gornje Podunavlje SNR is on satisfying level. & 2.08 & .52 \\
\hline Ecotourism in the Gornje Podunavlje SNR is optimally developed. & 2.17 & .84 \\
\hline $\begin{array}{l}\text { The local community is sufficiently involved in tourism of the Gornje Podunavlje } \\
\text { SNR. }\end{array}$ & 2.50 & .91 \\
\hline Tourism in localities Karapandža, Štrbac and Bestrement & 3.36 & .55 \\
\hline $\begin{array}{l}\text { Tours across the educational paths in Karapandža represent a threat for protected } \\
\text { species and habitats. }\end{array}$ & 2.08 & 1.31 \\
\hline $\begin{array}{l}\text { Tours across the educational path in Štrbac represent a threat for protected } \\
\text { species and habitats. }\end{array}$ & 2.17 & 1.19 \\
\hline $\begin{array}{l}\text { Tours across the educational path in Bestrement represent a threat for protected } \\
\text { species and habitats. }\end{array}$ & 2.17 & 1.19 \\
\hline $\begin{array}{l}\text { Karapandža, Štrbac and Bestrement encompass some of the most important } \\
\text { values of the Gornje Podunavlje SNR. }\end{array}$ & 4.92 & .29 \\
\hline $\begin{array}{l}\text { Ecotourism within Karapandža, Štrbac and Bestrement might contribute to gaining } \\
\text { complete experience of the Gornje Podunavlje SNR. }\end{array}$ & 4.10 & .99 \\
\hline $\begin{array}{l}\text { Ecotourism (education, interpretation) should be developed on the other localities } \\
\text { within the Gornje Podunavlje SNR, outside three researched ones. }\end{array}$ & 4.00 & 1.28 \\
\hline $\begin{array}{l}\text { Ecotourism within Karapandža, Štrbac and Bestrement encourages nature } \\
\text { protection. }\end{array}$ & 4.42 & .52 \\
\hline
\end{tabular}

\section{Discussion}

According to the main findings of the previous research, assessment of the impact of tourism activities on natural resources within the paths, including the monitoring the plant and animal species, represents important step in minimizing negative effects of ecotourism (Asmelash, \& Kumar, 2019; Blancas et al., 2016; Laimer, 2017; Kristjánsdóttir et al., 2018; Mapjabil et al., 2017; Pablo-Cea et al., 2020). Considering the fact that ecotourism represents a growing industry, further research of this type are of particular importance (Carvache-Franco et al., 2020).

Experts for nature protection expressed their attitudes on whether the plant species within Karapandža, Štrbac and Bestrement are sensitive in relation to ecotourism activities.
Employees in the Gornje Podunavlje SNR Authority believe that plant species are not sensitive or endangered, because they are not located in immediate vicinity of the walking paths, nor do visitors move without the supervision of guides' professional service. Most of INCVP experts also believe that plant species are not threaten. However, these experts believe that potential impact on sensitive plant species is possible in the narrowest zone of the visitors' movement, where visitors usually stay longer. University professors consider that adequate spatial planning of the walking paths might reduce the negative impact of further tourism development. Planning should be careful and under the professional supervision, considering the fact that some threats for the plant species are not obvious and they 
are not easy to predict. For example, trampling might contribute to dispersing invasive plants, which is confirmed in the study conducted by Buckley (2004a). Besides that, Ballantyne and Pickering (2012) considered the ecotourism as a threatening process for wild orchids, on the basis of other human activities, such as direct collecting and habitat clearance. Authors of the same study suggested that it is important to provide comprehensive evaluations of the range of impacts and species affected by tourism and the field assessments of tourism impacts, in order to provide a basis of knowledge for reducing the negative impacts of ecotourism (Ballantyne \& Pickering, 2012). In terms of the protected plant species within the Gornje Podunavlje SNR, University professors indicated that water-violets or water-lilies, for example, are not endangered, considering the fact that info boards are set across the protected localities, while the entire destination have the image related to nature conservation.

In case of the animal species sensitivity within Karapandža, Štrbac and Bestrement, in relation to ecotourism activities, experts for nature protection pointed out that it is necessary to consider the main characteristics of these important sites.

The same as in the case of the plant species, employees in the Gornje Podunavlje SNR Authority also believe that animal species are not endangered at the moment. However, they also believe that there is a potential threat in the case of opening the additional localities for tourists. This is important to keep in mind, considering the fact that there are periods during the year when reproduction of the animal species takes place and when all activities are suspended, including the movement of people, employees and local population. These findings are in line with the previously conducted studies which indicated the importance of considering the main characteristics of localities and protected species, when prescribing concrete measures for each path separately (Hockett et al., 2017; Kidd etal., 2015; Tomczyk \& Ewertowski, 2013).

INCVP experts are indicating that Karapandža is characterized by the animal species, such as wild cats, Štrbac is a specific site where deer and other game species are inhabited, while Bestrement is a habitat of butterflies - such as freyer's purple emperor (Apatura metis). In that regard, Lemelin and Jaramillo-López, (2020) researched the role of tourism in a conservation of the Monarch butterfly and they also highlighted the need to design a special protection measures for tourists' behavior within the site of protected species (Lemelin \& Jaramillo-López, 2020).

University professors indicated that the most important bird species in the Gornje Podunavlje SNR are white-tailed eagle and black stork, that are extremely sensitive to the people's presence in a relatively large radius around the nest (there are different recommendations for restricting the movement in different $\mathrm{Eu}-$ ropean countries - from several hundred meters, up to more than one $\mathrm{km}$ ).

Specific measures in the process of the ecotourism realization need to be adjusted to concrete sites and natural resources that are dominant within each of them.

Employees in the Gornje Podunavlje SNR Authority indicated that scope of the visit is not so large to endanger the most important natural values at the moment. In later stages (when the number of visits per day would account more than 200 visitors), some of the additional measures will certainly be needed. INCVP experts highlighted that there is a need to accurately prescribe the time dynamics of eco-tours, considering the time allowed for staying within the sensitive points of the Gornje Podunavlje SNR, together with controlling the size of the group of visitors. Besides that, they also emphasized the importance of limiting the visits during the week, especially during the critical periods, when plant and animal species are sensitive to disturbance. Finally, University professors indicated that protection of species and habitats must remain the primary function of the area, while ecotourism should be implemented only in a sustainable manner. There are many examples of a good practice of ecotourism development in particularly important natural areas around the world, and especially in Europe. All of these examples are indicating the fact that, during development of ecotourism, the emphasis should be on educating the visitors, as well as on sustainable involvement of the local community (Šiljeg et al., 2019).

Gornje Podunavlje SNR represents an important protected area, not only in Serbia, but also in wider terms, considering its international importance. No matter the fact, this protected area is still in the initial base of developing the ecotourism, which imposes the contribution of this research to a very limited literature regarding the assessment of tourism development to protected natural values of this site. Besides that, current circumstances caused by the COVID-19 pandemic indicated the fact that nature will have important role in further tourism recovery (Spalding et al., 2021). It means that it is expected that number of visitors in protected areas will increase in the following years, which imposes the additional contribution of this research, reflected in terms of providing the real assessment of the natural values before its further intensive tourism development. Finally, considering the previously mentioned fact that ecotourism represents a growing industry, further research of this type is of particular importance, especially from the experts for nature protection points of view. 


\section{Conclusion}

This research was oriented towards the assessment of the ecotourism impact on the environment within a destination that is in the process of development. The assessment of potential impacts was based on the attitudes of experts in the field of nature protection, who are introduced with the main characteristics of the Gornje Podunavlje SNR, primary with all characteristics of habitats, ecosystems, plant and animal species. The research results indicated that protected plant and animal species are not endangered by the current level of ecotourism and related tours across the educational paths, while potential negative impact could appear on the basis of further development. Besides theoretical contribution related to formation of the new questionnaire, the main findings of this research could find their practical implication in adjustment of further ecotourism activities to protection of natural values. Finally, it is important to indicate that this is a preliminary research that provided a knowledge basis on the experts' experience in the ecotourism development, which is highlighting the fact that monitoring of plant and animal species within ecotourism sites should be a priority. Interestingly, employees in the Gornje Podunavlje SNR Authority see less opportunities regarding the fact that nature protection projects might be financed from the incomes realized on the basis of providing tourism services, comparing to the perception of the other two groups of the nature protection experts within the sample. This is not surprising, keeping in mind that there are isolated cases in Serbia that have succeeded in ecotourism regarding the financial issue. Therefore, it is necessary to encourage them and train them through examples of a good practice to position themselves more adequately on the tourism market.

Besides theoretical contribution in the field of providing the knowledge base related to insufficiently researched ecotourism assessment on protected area with expressed potential for further tourism development, such as Gornje Podunavlje SNR, this research also provides potential for practical implication of the research results. More precisely, it provides the basic findings regarding the main issues in terms of the nature protection, which might be used in the form of guidance for further tourism development that will not endanger vulnerable resources, such as plant and animal species. The research results also provided a basis for establishing the further research frame that will be constructed in line with the main issues of nature protection in protected areas. Findings might serve not only to Gornje Podunavlje SNR, but to other widely spread protected areas. Besides theoretical and practical contributions, this research also contains several limitations, mainly related to the number of the respondents within the sample and general construction of the question items for the purpose of the pilot study. Removals of these limitations are planned within the next more detailed study, while similar researches might be conducted within other protected areas.

\section{References}

Asmelash, A. G., \& Kumar, S. (2019). Assessing progress of tourism sustainability: Developing and validating sustainability indicators. Tourism Management, 71, 67-83.

Ballantyne, M., \& Pickering, C. (2012). Ecotourism as a threatening process for wild orchids. Journal of Ecotourism, 11(1), 34-47.

Blancas, F. J., Lozano-Oyola, M., González, M., \& Caballero, R. (2016). Sustainable tourism composite indicators: A dynamic evaluation to manage changes in sustainability. Journal of Sustainable Tourism, 24(10), 1403-1424.

Buckley, R.C. (2001). Environmental impacts of ecotourism. In D. Weaver (ed.) Encyclopedia of Ecotourism (pp. 379-394). London: CABI International.

Buckley, R.C. (2004a). Impacts of Ecotourism on Birds. In R. Buckley (ed.) Environmental Impacts of
Ecotourism (pp. 187-209). London: CABI Publishing.

Buckley, R.C. (2004b). Impacts of Ecotourism on Terrestrial Wildlife. In R. Buckley (ed.) Environmental Impacts of Ecotourism (pp. 211-228). London: CABI Publishing.

Buckley, R.C. (2004c). Impacts Positive and Negative: Links Between Ecotourism and Environment. In R. Buckley (ed.) Environmental Impacts of Ecotourism (pp. 5-14). Wallingford: CABI Publishing.

Carvache-Franco, M., Perez-Orozco, A., CarvacheFranco, O., Víquez-Paniagua, A. G., \& CarvacheFranco, W. (2020). The perceived value in ecotourism related to satisfaction and loyalty: A study from Costa Rica. Geographica Pannonica, 24(3), 229-243. Ceballos-Lascura 'in, H. (1996). Tourism, ecotourism, and protected areas. IUCN protected areas pro- 
gramme. Gland: IUCN (World Conservation Union). https://doi.org/10.2305/IUCN.CH.1996.7.en

Christ, C., Hillel, O., Matus, S., \& Sweeting, J. (2003). Tourism and biodiversity mapping tourism's global footprint. Washington, DC: Conservation International (CI).

Donohoe, H. M., \& Needham, R. D. (2006). Ecotourism: The evolving contemporary definition. Journal of Ecotourism, 5(3), 192-210.

Eagles, P. F., McCool, S. F., \& Haynes, C. D. (2002). Sustainable tourism in protected areas: Guidelines for planning and management (No. 8). Gland, Switzerland and Cambridge, UK: IUCN.

Goodwin, H. (2009). Reflections on 10 years of propoor tourism. Journal of Policy Research in Tourism, Leisure and Events, 1(1), 90-94. https://doi. org/10.1080/19407960802703565

Hockett, K. S., Marion, J. L., \& Leung, Y. F. (2017). The efficacy of combined educational and site management actions in reducing off-trail hiking in an urban-proximate protected area. Journal of environmental management, 203, 17-28.

Kidd, A. M., Monz, C., D’Antonio, A., Manning, R. E., Reigner, N., Goonan, K. A., \& Jacobi, C. (2015). The effect of minimum impact education on visitor spatial behavior in parks and protected areas: An experimental investigation using GPS-based tracking. Journal of environmental management, 162, 53-62.

Kristjánsdóttir, K. R., Ólafsdóttir, R., \& Ragnarsdóttir, K. V. (2018). Reviewing integrated sustainability indicators for tourism. Journal of Sustainable Tourism, 26(4), 583-599.

Kvale, S. (1996). InterViews. CA: Thousand Oaks, Sage. Laimer, P. (2017). Tourism Indicators for Monitoring the SDGs. In Sixth UNWTO International Conference on Tourism Statistics, Manila, Philippines (pp. 21-24).

Lazić, L., Pavić, D., Stojanović, V., Tomić, P., Romelić, J., Pivac, T., Košić, K., Besermenji, S., Kicošev, S., Đarmati, Z., Puzović, S., Đureković-Tešić, O., Stojanović, T., Marić, B., Vig, L., Panjković, B., Habijan-Mikeš, V., Sabadoš, K., Delić, J., Kovačević, B., Stojšić, V., \& Korać, J. (2008). Protected areas and ecotourism of Vojvodina. Novi Sad: Faculty of Sciences, Department of Geography, Tourism and Hotel Management, (in Serbian),

Lemelin, R. H., \& Jaramillo-López, P. F. (2020). Orange, black, and a little bit of white is the new shade of conservation: the role of tourism in Monarch
Butterfly Conservation in Mexico. Journal of Ecotourism, 19(4), 291-303.

Lévêque, C., \& Mounolou, J., C., (2003). Biodiversity. Chichester: John Wiley \& Sons, Ltd.

Mapjabil, J., Marzuki, M., Zainol, R. M., Jusoh, A. T. M., \& Ramli, R. S. (2017). Applying sustainability indicators to eco-tourism development: The case of Jeram Linang Amenity Forest, Kelantan. Geografia-Malaysian Journal of Society and Space, 11(12).

Ministry of Environmental Protection (2007). Protected natural resources in Serbia. Belgrade.

Pablo-Cea, J. D., Velado-Cano, M. A., \& Noriega, J. A. (2021). A first step to evaluate the impact of ecotourism on biodiversity in El Salvador: a case study using dung beetles in a National Park. Journal of Ecotourism, 20(1), 51-69.

Panjković, B., \& Stojnić, N. (2011). Biodiversity and protected areas. In Puzović S., \& RadovanovićJovin H. (eds.). Environment in the Autonomous Province of Vojvodina. Novi Sad: Provincial Secretariat for Urban Planning, Construction and Environmental Protection.

Robson, C., \& McCartan, K. (2016). Real world research. John Wiley \& Sons.

Šiljeg, A., Cavrić, B., Šiljeg, S., Marić, I., \& Barada, M. (2019). Land suitability zoning for ecotourism planning and development of Dikgatlhong Dam, Botswana. Geographica Pannonica, 23(2), 76-86.

Spalding, M., Burke, L., \& Fyall, A. (2021). Covid-19: Implications for nature and tourism. Anatolia, 32(1), 126-127.

Stojanović, V., Lazić, L., \& Dunjić, J. (2018). Nature protection and sustainable tourism interaction in selected Ramsar sites in Vojvodina (Northern Serbia). Geographica Pannonica, 22(3), 201-207.

Terry, G., Hayfield, N., Clarke, V., \& Braun, V. (2017). Thematic analysis. In C. Willig, \& W. Stainton-Rogers (eds.) The Sage handbook of qualitative research in psychology (pp. 17-37 pp.). London, UK: Sage Publishing.

Tomczyk, A. M., \& Ewertowski, M. (2013). Planning of recreational trails in protected areas: Application of regression tree analysis and geographic information systems. Applied Geography, 40, 129-139. Tucakov, M., (2018). Protected areas in the Biosphere Reserve are its most valuable resource. In D. Zagorac (ed.) Bačko Podunavlje Biosphere Reserve - Nature and People (pp. 68-76). Novi Sad: Provincial Secretariat for Urban Planning and Environmental Protection, Institute for Nature Conservation of Vojvodina Province. 